This is an Accepted Manuscript of an article published by Taylor \& Francis in Innovations in Education and Teaching International (2015), available

online: $h$ ttp://dx.dol.org/10.1080/14703297.2015.1013145 [DOI:

10.1080/14703297.2015.1013145].

\title{
Understanding the gender and ethnicity attainment gap in UK
}

\section{higher education}

Cotton, D.R.E ${ }^{* a}$, Joyner, M. ${ }^{\text {b }}$ George, R. ${ }^{\mathrm{a}}$ \& Cotton, P.A. ${ }^{\mathrm{c}}$

${ }^{a}$ Pedagogic Research Institute and Observatory (PedRIO), Plymouth University, Plymouth

UK; ${ }^{b}$ Faculty of Health and Human Sciences, Plymouth University, Plymouth, UK; ${ }^{c}$ School of Marine Science and Engineering, Plymouth University, Plymouth, UK.

\section{Postal address for correspondence}

Professor Debby Cotton,

Pedagogic Research Institute and Observatory (PedRIO),

Plymouth University,

Plymouth,

Devon, PL4 8AA

dcotton@plymouth.ac.uk

In recent years the success rates of different groups of students in higher education (HE), have come under considerable scrutiny, with gender and ethnicity identified as key attributes predicting differential achievement of 'good degrees'. A review of previous studies highlights the need for research which looks beyond 'the deficit model' to explain the attainment gap. This research used a mixed-methods approach to explore the academic and social experiences of students, as well as lecturers' views on student achievement, in one UK University. Findings suggest that there are significant differences in motivation and confidence speaking English for different ethnic groups in this study, and a divergence in attendance and study time

\footnotetext{
* Corresponding author. Email: dcotton@plymouth.ac.uk
} 
This is an Accepted Manuscript of an article published by Taylor \& Francis in Innovations in Education and Teaching International (2015), available

online: $h$ ttp://dx.dol.org/10.1080/14703297.2015.1013145 [DOI:

10.1080/14703297.2015.1013145].

by gender - both of which may go some way to helping understand the gaps in attainment. In addition, male and BME students tended to over-estimate their likelihood of achieving a good degree outcome, compared to other groups.

Keywords: Gender, Ethnicity, Diversity, Inclusivity, Attainment

\section{Introduction}

This paper is concerned with exploring the gaps in attainment in higher education (HE) which have been observed between different groups of students. It draws on previous research to explore aspects of the student experience which may help make sense of differential attainment. The key issues can be summarised as follows:

1. Students from most ethnic minority backgrounds obtain poorer degree results than white students, even when controlling for prior attainment, age, gender and discipline.

2. Female students achieve better degree classifications than male students, except when it comes to attaining a first class degree, where there is no significant difference (Broecke \& Nicholls, 2008; HEFCE, 2014).

Much of the research on student attainment has been quantitative and focused on identifying student characteristics that could influence attainment. Fielding, Charlton, Kounali and Leckie (2007) analysed data from the National Student Survey (NSS) and the Higher Education Statistics Agency (HESA) to study patterns of association between attainment and socio-economic factors. They found that entry qualifications, gender and type of institution attended might influence attainment, and indicated that BME males do less well 
This is an Accepted Manuscript of an article published by Taylor \& Francis in Innovations in Education and Teaching International (2015), available

online: $h$ ttp://dx.dol.org/10.1080/14703297.2015.1013145 [DOI:

10.1080/14703297.2015.1013145].

than BME females. Moreover, institutions with a higher proportion of BME students tended to have greater differentials in attainment.

Leslie (2005) suggested that the reasons for low attainment of BME groups may be connected to their relatively higher participation rates, which resulted in lower prior attainment. This has been explored further by Richardson (2008) who demonstrated that the likelihood of BME students attaining a good degree increased by roughly $50 \%$ when the effects of entry qualifications were controlled. However, the study also found that the effects of age, gender, mode and subject of study all interacted with ethnicity (Richardson, 2008) making it problematic to discern causality with respect to any single factor. This intersectionality of different background variables is also discussed by Strand (2014), who concludes that researchers should 'develop more nuanced accounts of educational success or failure' (p. 165).

Despite considerable interest in this area, there has been relatively little research exploring the impact of university environment and student experience on degree outcomes. Literature on student retention has identified a number of key aspects of the student experience which impact on withdrawal rates, and arguably on chances of success. For example, Tinto (1993) identifies aspects of the academic environment (including interaction with faculty) and social system (such as extra-curricular activities and peer-group integration) as playing a key role in the student experience. He concludes that students who are less well integrated are more likely to withdraw. Tinto's model has implications for research into attainment, since it provides fruitful areas for investigating differences in the student experience. Previous research which has utilised Tinto's model in the UK suggests that, 'on average, ethnic minority students have less contact with their fellow students and teachers, and are, therefore, less socially and academically integrated' (Meeuwiss, Severiens \& Born, 
This is an Accepted Manuscript of an article published by Taylor \& Francis in Innovations in Education and Teaching International (2015), available

online: $h$ ttp://dx.dol.org/10.1080/14703297.2015.1013145 [DOI:

10.1080/14703297.2015.1013145].

2010, p. 94). However, this is unlikely to provide a plausible explanation for male underattainment.

A further variable identified in a study by Ridley (2007) was the impact of less effective forms of study behaviour within BME student groups. Ridley's research suggested that black students were more likely to use a 'surface approach' to studying when compared to white groups, and use of a surface approach was found to be negatively correlated with marks in exams and coursework. Another study (Dart et al., 1999) suggests that male students are more likely to adopt a surface learning approach so this may provide a partial explanation for attainment gaps. Claims have also been made that exams favour males and coursework females (Martin, 1997), and the increasing move toward coursework could be a contributory factor to the gender attainment gap. At the University of Oxford, where many courses are assessed on the basis of exams at the end of the final year, the gender gap is reversed - at least in terms of the proportion of students achieving first class degrees (Trigwell \& Ashwin, 2003).

Finally, Stuart, Lido, Morgan and May (2008) conducted a study which focused on student experience of extra-curricular activities and impact on attainment. They looked at differences in the kinds of activities that students participated in, based on their socio-cultural backgrounds. Compared to students from ethnic minority backgrounds, white students spent more time with friends and in clubs and bars, and were involved in more university-based activities. Black students spent more time in the library, with their families, were involved in more solitary activities and fewer university based activities (Stuart et al., 2008, p.54). Whilst this may reflect differences in integration into university life, it seems difficult to conclude that spending more time in bars is likely to enhance directly the chances of academic success. In addition, this study also showed that male students spent more time in pubs and bars, on 
This is an Accepted Manuscript of an article published by Taylor \& Francis in Innovations in Education and Teaching International (2015), available

online: $h$ ttp://dx.dol.org/10.1080/14703297.2015.1013145 [DOI:

10.1080/14703297.2015.1013145].

sports and sitting on councils and committees than did female students (Stuart et al., 2008, p.51).

Richardson (2008), in a review of existing literature, notes that the contingent nature of observed attainment gaps, 'suggests that [they are] at least partly attributable to variations in the students' academic context rather than to inherent or constitutional characteristics within the students themselves.' (p.14). This highlights a need to look beyond 'the deficit model' to explain the attainment gap. A research study conducted at the University of Wolverhampton revealed a lack of adequate awareness of the needs of non-traditional students and underdeveloped student support systems (Pinnock, 2008). Institutional racism and the role of indirect discrimination have also been mentioned as possible influences (Connor, Tyers, Modood \& Hillage, 2004).

In the light of the gaps in existing research findings, the need for further investigation was identified, and for research which considered the academic environment as well as expectations and experiences of university more widely. Our study sought to collect accounts of university life from various student groups, and consider their potential impact on attainment in the context of a university in the South West of England. This institution provides an interesting case study, owing to its position in a locality which has low numbers of ethnic minority students (and local residents). Unusually, the study also examined both faculty and students' perspectives on the attainment gap. 
This is an Accepted Manuscript of an article published by Taylor \& Francis in Innovations in Education and Teaching International (2015), available

online: $h$ ttp://dx.dol.org/10.1080/14703297.2015.1013145 [DOI:

10.1080/14703297.2015.1013145].

\section{Aims and objectives}

The primary aim of the project was to investigate differences in attainment by comparing student experiences based on ethnicity and gender. This was accomplished by:

- Collecting and analysing student accounts of study and social experiences that may impact on attainment

- Collecting and analysing faculty accounts of teaching different groups of students

- Comparing differences in experiences of BME, white, male and female students.

This approach does not seek to provide a causal or predictive model of the factors influencing attainment. Instead, it seeks to uncover the unique and individual student experiences that may help explain the gaps in attainment.

\section{Methodology}

The researchers used a mixed methods approach in which triangulation of both data sources and methods were adopted. Data were collected from both students and faculty members in six academic schools (departments) with different characteristics in terms of student population and outcomes (see Table 1). The research was conceived as an 'instrumental' case study (Stake, 1995), which uses a single university as a proxy for other institutions with similar patterns of entry and achievement.

Table 1 about here 
This is an Accepted Manuscript of an article published by Taylor \& Francis in Innovations in Education and Teaching International (2015), available

online: http://dx.doi.org/10.1080/14703297.2015.1013145 [DOI:

10.1080/14703297.2015.1013145].

The purposive sample was selected to provide a range student perspectives: within the constraints of this paper, no attempt is made to draw out differences between the different departments.

The three methods of data collection were:

- An online questionnaire sent to all undergraduate students in the selected schools. A total of 6000 students were contacted from which 1023 responses (49 Female BME, 382 Female White, 44 Male BME, 548 Male White) were obtained, giving a response rate of $17 \%$.

- Six focus group discussions with targeted student groups (2 groups of white female home students; 2 groups of white male students; BME home students of both genders; BME overseas students of both genders - 28 students in total).

- Semi-structured interviews with a minimum of two faculty in each school (21 in total).

Quantitative data from the questionnaires were analysed with SPSS19. For the analysis of Likert items we followed the principles outlined by Kuzon et al. (1996) and used Kruskal Wallis tests to explore differences between the groups of students (Female-White, FemaleBME, Male-White, Male-BME). Because there were 14 separate questions, we used Bonferroni correction $(\mathrm{a}=0.0036)$ to minimise the possibility of Type II errors. Post-hoc pairwise comparisons were conducted using Dunn's procedure with the significance levels adjusted for multiple testing.

Qualitative data were analysed in NVivo using the constant comparative method to draw out cross-cutting themes (Silverman, 2005). The emergent themes from the qualitative 
This is an Accepted Manuscript of an article published by Taylor \& Francis in Innovations in Education and Teaching International (2015), available

online: $h$ ttp://dx.dol.org/10.1080/14703297.2015.1013145 [DOI:

10.1080/14703297.2015.1013145].

data were compared with the findings from the quantitative data, and used to add depth to the findings from the statistical analysis.

It is not possible to describe, in a brief paper, all the findings of the research. This paper is therefore structured around key significant differences which were found between the groups of students. When analysed separately, there were significant differences for six Likert items. Bonferroni correcting for 14 separate tests $(\mathrm{a}=0.0036)$ leaves five significant results shown below:

1. "I believe that a university education is very important" (Kruskal Wallis $c^{2}{ }_{3}=22.215$, $\mathrm{p}<0.0001$ ). Post-hoc tests showed no significant difference between male BME and female BME students, but both gave this statement a significantly higher score than white students.

2. "It was very important for my family that I attend university" (Kruskal Wallis $c^{2}{ }_{3}=$ 62.183, $\mathrm{p}<0.0001)$. As with the previous item, there was a very clear difference between students of different ethnic backgrounds, with BME students of both genders scoring more highly.

3. "Outside of class time, how many hours a week do you spend studying on average?" (Kruskal Wallis $c^{2}{ }_{3}=20.550, \mathrm{p}<0.0001$ ). The only test that was significant was that between female white and male white students. Female white students recorded the highest score, followed by male BME, female BME and finally male white students.

4. "I feel anxious before an exam or class assessment" (Kruskal Wallis $c^{2}{ }_{3}=33.482$, $\mathrm{p}<0.0001)$. Here there is clear evidence of a gender difference: female white and female 
This is an Accepted Manuscript of an article published by Taylor \& Francis in Innovations in Education and Teaching International (2015), available

online: $h$ ttp://dx.dol.org/10.1080/14703297.2015.1013145 [DOI:

10.1080/14703297.2015.1013145].

BME did not differ significantly in their scores which were significantly higher than the scores for both male white and male BME students.

5. "I am comfortable speaking in English to my friends and classmates at the University" (Kruskal Wallis $c^{2}{ }_{3}=27.554, \mathrm{p}<0.0001$ ). Here we see a very clear ethnicity difference: female and male white students did not differ significantly in their scores, but their score was significantly higher than those for male and female BME students.

The sixth item that was dropped following Bonferroni correction was "I feel part of the social life at the University" (Kruskal Wallis $\left.c^{2}{ }_{3}=13.526, \mathrm{p}<0.00362, \mathrm{a}=0.00357\right)$. Although we need to be cautious in interpreting this result, because of the possibility of a Type II error, there appears to be an ethnicity effect as white students scored higher than BME students.

These findings suggest that the main differences in experience were in terms of motivation to attend university (items 1 and 2 above); anxiety and study time (items 3 and 4 above); and spoken English - possibly linked to social integration (items 5 and 6 above). These key issues are discussed further below in the light of additional data from interviews and focus groups.

\section{a) Motivation:}

Focus group data support the finding that BME students felt that university participation was more important generally and were influenced by their family:

My parents they have very much expectation on me, they want me to do higher, higher, higher stuff. Maybe I will plan for my masters next. (Male BME overseas student) 
This is an Accepted Manuscript of an article published by Taylor \& Francis in Innovations in Education and Teaching International (2015), available

online: $h$ ttp://dx.dol.org/10.1080/14703297.2015.1013145 [DOI:

10.1080/14703297.2015.1013145].

...because my father wanted me to get a higher education. So it's going to be better for me when I graduate, then I might find a good job. (Female BME home student)

In addition, there is some indication that BME students were more likely to be extrinsically motivated (by course reputation or future career), while white students were more likely to be intrinsically motivated (by interest in the subject, personal development etc.):

I wanted to do a course ... where I can go places ... I would like to be in a job where I know, even if I go to Africa or if I stay in Europe I'll still have a job. (Female BME home student)

Yes I'm here to get a degree but I'm more here for the experience, to meet educated people, to go for opportunities (White female home student)

The influence of family might result in BME students choosing courses in which they have little interest. Faculty interviews highlighted instances of BME students who were unhappy with their choice of programme, an issue which they attributed to family influence:

One [student] was here last week ... she's not doing very well. She doesn't really like accounting and finance but she wants to do a Masters and I said well why are you doing a Masters if you don't like the subject? And she said because my father says I have to. I'd like to be a singer. (Business faculty)

Whilst a belief in the importance of a university education ought to enhance motivation, a focus on extrinsic factors may mean that some BME students lack a deep engagement with the subject and adopt surface approaches to learning. 
This is an Accepted Manuscript of an article published by Taylor \& Francis in Innovations in Education and Teaching International (2015), available

online: $h$ ttp://dx.dol.org/10.1080/14703297.2015.1013145 [DOI:

10.1080/14703297.2015.1013145].

\section{b) Anxiety and study time:}

The quantitative findings indicate that female students were more anxious about exams and assessments than male students and this was reflected in focus groups:

I'm doing alright at the moment, but I'm one of those people that's just, but it's not good enough, I can't do it ... I'm definitely going to fail the next exam. (White female home student)

However, whilst anxiety would usually be associated with negative educational outcomes, our findings suggest that male over-confidence may be a contributory factor in their underperformance. In one part of the questionnaire, students were asked to predict their likely degree outcome, and these predictions were compared with actual results from previous cohorts (using recent data for each group). From this comparison, it is clear that male students and BME overseas students over-estimate their likely degree outcomes (see figure 1):

Figure 1 about here

Clearly all groups of students are somewhat optimistic about the chances of achieving a 'good degree', but this is strongest for groups who currently underperform. This may be indicative of a lack of understanding of the expectations of HE study - or perhaps of marker bias, as suggested by one BME student.

For male students, a sense of over-confidence in their own ability may lead to an under-commitment in terms of study time - as indicated by the quantitative data. Faculty (and students') perceptions were that female students tended to be more hard-working and organised: 
This is an Accepted Manuscript of an article published by Taylor \& Francis in Innovations in Education and Teaching International (2015), available

online: $h$ ttp://dx.dol.org/10.1080/14703297.2015.1013145 [DOI:

10.1080/14703297.2015.1013145].

Generally speaking I think that girls are more dedicated and get on with it whereas some boys will leave it till the last minute and do the minimum. But that's a bit of a generalisation (Biology faculty)

The girls seem to just be a lot more organised, whereas a lot of the guys ... quite easily forget things.. (White male home student)

In addition, male students (at a reported 30.7\%) were almost twice as likely to miss at least one class a week than female students (16.5\%), with obvious knock-on effects on achievement.

\section{c) Spoken English and social integration}

The quantitative findings show that white students were more comfortable speaking English than BME students. English language ability was raised by students and faculty as a key factor influencing success, and something may impede attainment for some BME students:

People come from a very different educational background but that doesn't prevent them doing well, what prevents them doing well is not having the language ability. (Business faculty)

And the difference is that in China the teacher will speak Chinese, use Chinese to explain ... Here absolutely it's English. (BME overseas female student)

Whilst there was no significant difference in 'feeling part of the social life' among the student groups after Bonferroni correction, white students scored higher on this statement. In the focus groups BME students reported facing issues of integration and mixing with white 
This is an Accepted Manuscript of an article published by Taylor \& Francis in Innovations in Education and Teaching International (2015), available

online: $h$ ttp://dx.dol.org/10.1080/14703297.2015.1013145 [DOI:

10.1080/14703297.2015.1013145].

students. Opinions varied on whether this was an explicit choice to socialise in homogenous groups - or a response to difficulties encountered in integrating with home students:

I know a lot of Chinese students here and they were just by themselves or in a house with other Chinese students and they'd keep to themselves (White female home student)

Only foreign students talk to us, the others I don't know why, maybe they think our English is no good, or something else, they just don't like communicating. (Female BME overseas student)

Faculty reported that adjustment to university life was an issue for all students in the first year, but particularly for overseas students who might come from a very different culture:

In China ... they're culturally used to accepting everything that person says, because they're the expert. ... So they've got to try to adapt to a different higher education system. (Business faculty)

The qualitative data also suggest that while male students placed more importance on the social aspects of university life, with female students placing importance on academic aspects. Students suggested that involvement in sports and the drinking culture might impact on academic work (for white male students). 
This is an Accepted Manuscript of an article published by Taylor \& Francis in Innovations in Education and Teaching International (2015), available

online: $h$ ttp://dx.dol.org/10.1080/14703297.2015.1013145 [DOI:

10.1080/14703297.2015.1013145].

\section{Discussion}

\section{Understanding gender differences}

According to the findings of this study, one of the key reasons for the differential attainment of male and female students is the divergence in study time by gender. It could be argued that male students perform less well in HE simply because they study less and are more likely to skip classes than their female counterparts. While there may be some degree of self-report bias - with male students reticent to admit to working hard - the views of faculty correlated very strongly with the students' self-reports.

Grebennikov and Skaines (2009) claim simply that, 'Women seem to take higher education more seriously than men' (p. 71); however, data from the focus groups suggest that there may be social barriers to indulging in study-related activities for male students, with the negative associations of being a 'geek' and a lack of social support for study. Previous research shows that female students are more co-operative while working (Askew \& Ross, 1988), and that rejecting academic work serves the purposes of social identity construction amongst male peer groups in school, while providing an excuse for failure (Jackson, 2003). It was notable that when faculty were asked to describe the characteristics of a successful student, they attributed many of these qualities to female students.

The focus group data suggest that male students are more engaged in sport-related extra-curricular activities which may impact on the time available for study. Although participating in wider activities at university is generally considered beneficial both in terms of learning and employability, research by Eide and Ronan (2001) in the US indicates that participation in varsity sports has a negative effect on the educational attainment of white male students (although a positive effect on black male students). 
This is an Accepted Manuscript of an article published by Taylor \& Francis in Innovations in Education and Teaching International (2015), available

online: $h$ ttp://dx.dol.org/10.1080/14703297.2015.1013145 [DOI:

10.1080/14703297.2015.1013145].

There are also observed differences in terms of assessment anxiety experienced by male and female students. This is in line with other findings, such as Trigwell and Ashwin (2003) who note that male students are more confident than female students in their ability to do well. Indeed, the confidence of male students has been used to account for their success in some HE contexts: 'There may be an element of a 'self-fulfilling prophecy' here, such that male students' beliefs that they will do better leads to them performing better' (Trigwell \& Ashwin, 2003, p. 47). In contrast, we would argue that the confidence of some male students is unwarranted, and in terms of independent study leads them to do 'too little, too late'. Last minute preparation - described by both faculty and students as indicative of some male students - may lead to use of more surface learning approaches. This is an issue which would benefit from further exploration.

\section{Understanding ethnicity differences}

Interpreting the data on ethnicity in this study is problematic, particularly because of the relatively small number of BME students involved, and the difficulties in disentangling the issues relating to non-native English speakers (a significant proportion of the 'home' BME students were not native speakers). There is no evidence that BME students spend less time studying or are more likely to skip lectures than white students: Self-reported study time indicates no difference between these groups. Indeed, many faculty viewed BME overseas students as being very hardworking and motivated compared to home students. It seems unlikely therefore that study-related factors are sufficient to explain the attainment gap. In many ways, BME overseas students had similar behavioural habits to female students, who perform very well in HE. 
This is an Accepted Manuscript of an article published by Taylor \& Francis in Innovations in Education and Teaching International (2015), available

online: $h$ ttp://dx.dol.org/10.1080/14703297.2015.1013145 [DOI:

10.1080/14703297.2015.1013145].

The difference in motivation between white and BME students could provide a partial explanation for attainment differences if it results in a lower engagement with the subject. However, although we can posit a relationship between extrinsic motivation for participation in HE and possible adoption of a surface approach to learning, we have little direct evidence in support of this link. Moreover, family encouragement and support to attend university and to achieve well is generally considered to have a positive influence on academic outcomes therefore this would warrant further exploration.

Perhaps more telling is the finding that, as with male students, there were a higher proportion of BME overseas students who over-estimated their chances of achieving a good degree. This may be indicative of a lack of understanding of the UK HE system. Differences in 'social capital' (Bourdieu, 1997) within the unfamiliar context may be a significant factor which hinders international students' success in HE. Whilst many students find the transition to first year problematic, this may be especially significant for BME overseas students who continue to find social integration difficult throughout their time in HE.

Moreover, for those students with language difficulties, this may be exacerbated by the limited opportunities to engage with home students either in class or socially (reports of segregation were widespread). It is undeniably the case that the social infrastructure of the university caters primarily to a white home student audience. Previous research has emphasised that learners value social support and friendships highly (Yorke \& Longden, 2008), and the negative impact of being less well integrated has been widely reported, in particular with respect to student retention (Tinto, 1993) but with potential impacts on outcomes. 
This is an Accepted Manuscript of an article published by Taylor \& Francis in Innovations in Education and Teaching International (2015), available

online: $h$ ttp://dx.dol.org/10.1080/14703297.2015.1013145 [DOI:

10.1080/14703297.2015.1013145].

Although attitudes towards racism and discrimination varied amongst different groups of students, there were some hints that this may influence BME student integration, with racist incidents being report by some students. It was clear from this study that both faculty and students, whilst overtly expressing the view that they did not 'see' gender or ethnicity were influenced by widespread stereotypes about different types of students. Described by Palfreyman (2005) as a process of 'othering', the impact of these stereotypes on student success is a factor which would merit further exploration.

In particular, faculty interviews suggest that there was only limited engagement with a critical view of race and gender, and little reflection on the ways in which gender and ethnicity might influence interactions between faculty and students. As Willems (2010) notes, ‘...for groups of students who have been traditionally marginalised in academia to have parity in relation to access, participation and successful outcomes in higher education, some will need to be treated 'differently' to gain similar outcomes' (p. 604). The possibility of providing preferential treatment for particular underperforming groups was not raised in our study and the belief that faculty treated all students 'exactly the same' was widespread.

\section{Conclusions}

This research identified a number of differences between groups of students which may go some way towards helping to understand observed differences in attainment. Although the conclusions must remain provisional, based as they are on a single case study, they provide some interesting insights into divergent student experiences which might be tested in further research. There are three issues in particular which seem to warrant exploration as they may shed light on both the gender and ethnicity attainment gaps: 
This is an Accepted Manuscript of an article published by Taylor \& Francis in Innovations in Education and Teaching International (2015), available

online: $h$ ttp://dx.dol.org/10.1080/14703297.2015.1013145 [DOI:

10.1080/14703297.2015.1013145].

1. The possibility that both BME students and male students might be more likely to use surface learning approaches, thereby lowering attainment.

2. The tension between integration into university life and the potential negative impact of over-involvement in clubs or societies. This seems to be a delicate balance which could have divergent impacts on different student groups.

3. The importance for students of having an accurate understanding of their achievement levels. For whatever reason, both male and BME students were not effectively judging likely success.

These issues could provide useful additional guidance for students in terms of managing their time and effort at university. In addition, the research indicates the need for faculty development, since the lack of explicit consideration of ethnicity and gender may act as a barrier to cultural change.

\section{Notes on contributors}

Debby Cotton is Professor of Higher Education Pedagogy and Head of Educational Development at Plymouth University. She is based in the Pedagogic Research Institute and Observatory (PedRIO), and has published widely on a wide range of issues in higher education including sustainability education, inclusivity, research-informed teaching, and the hidden curriculum. She is a Principal Fellow of the Higher Education Academy (HEA) and current co-chair of the SEDA Research Committee.

Mel Joyner is the Associate Dean Teaching and Learning for the Faculty of Health and Human Sciences at Plymouth University. She is a social science academic, with specialisations in public policy and administration as well as quantitative research 
This is an Accepted Manuscript of an article published by Taylor \& Francis in Innovations in Education and Teaching International (2015), available

online: $h$ ttp://dx.dol.org/10.1080/14703297.2015.1013145 [DOI:

10.1080/14703297.2015.1013145].

methods. She is also a fellow of the Pedagogic Research Institute and Observatory (PedRIO) at Plymouth University.

Rosemary George is currently pursuing a doctorate in Anthropology and Sociology of Development at the Graduate Institute of International and Development Studies at Geneva. Prior to this, she was a Research Assistant in the Pedagogic Research Institute and Observatory (PedRIO) at Plymouth University. She holds a Masters in Media and Communication from the London School of Economics and Political Science.

Pete Cotton is an Associate Head of School for Marine Science and Engineering at Plymouth University and a senior lecturer in marine biology. He has a DPhil from Oxford University and has published widely on ecology, evolution, animal behaviour and more recently on pedagogic research. 
This is an Accepted Manuscript of an article published by Taylor \& Francis in Innovations in Education and Teaching International (2015), available

online: http://dx.doi.org/10.1080/14703297.2015.1013145 [DOI:

10.1080/14703297.2015.1013145].

\section{References:}

Askew, S., \& Ross, C. (1988). Boys don't cry: Boys and sexism in education. Milton Keynes: Open University Press.

Bourdieu, P. (1997). Forms of capital. In A. Halsey, H. Lauder, P. Brown, \& A. S. Wells (Eds.), Education: Culture, economy, and society, (46 - 58). Oxford: Oxford University Press.

Broecke, S., \& Nicholls, T. (2008). Ethnicity and degree attainment. (Research Report RW92). London: Department for Education and Skills.

Connor, H., Tyers, C., Modood, T., \& Hillage, J. (2004). Why the difference? A closer look at higher education minority ethnic students and graduates. Research Report RR552, Department for Education and Skills (DfES). Available online at: http://www.employment-studies.co.uk/pdflibrary/rr552.pdf (accessed 16/01/15)

Dart, B., Burnett, B., Boulron-Lweis, G., Campbell, J., Smith, D., \& McCrindle, A. (1999). Classroom learning environments and students' approaches to learning. Learning Environments Research, 2, 137-156.

Eide, E. R., \& Ronan, N. (2001). Is participation in high school athletics an investment or a consumption good? Evidence from high school and beyond. Economics of Education Review, 20, 431-442.

Fielding, A., Charlton, C., Kounali, D., \& Leckie, G. (2008). Degree attainment, ethnicity and gender: Interactions and the modification of effects - A quantitative analysis. York, UK: Equality Challenge Unit, Higher Education Academy. 
This is an Accepted Manuscript of an article published by Taylor \& Francis in Innovations in Education and Teaching International (2015), available

online: http://dx.doi.org/10.1080/14703297.2015.1013145 [DOI:

10.1080/14703297.2015.1013145].

Grebennikov, L., \& Skaines, I. (2009). Gender and higher education experience: a case study. Higher Education Research \& Development, 28, 71- 84.

HEFCE (2014). Differences in degree outcomes: Key findings. Issues Report. March 2014/03. Available online at:

http://www.hefce.ac.uk/media/hefce/content/pubs/2014/201403/HEFCE2014_03.pdf (accessed 16/3/15)

Jackson, C. (2003) Motives for 'laddishness' at school: Fear of failure and fear of the 'feminine'. British Educational Research Journal, 29, 583- 598.

Kuzon, W.M. Jr, Urbanchek, M.G. and McCabe, S. (1996) The seven deadly sins of statistical analysis. Annals of Plastic Surgery, 37, 265-272.

Leslie, D. (2005). Why people from the UK's minority ethnic communities achieve weaker degree results than whites. Applied Economics. 37, 619-32.

Martin, M. (1997) Emotional and cognitive effects of examination proximity in female and male students, Oxford Review of Education, 23, 479-486.

Meeuwisse, M , Severiens, S. E. \& Born, M. P. (2010). Reasons for withdrawal from higher vocational education. A comparison of ethnic minority and majority non-completers. Studies in Higher Education, 35, $93-111$

Palfreyman, D. (2005) Othering in an English language program. TESOL Quarterly, 39, 211233.

Pinnock, K (2008). Embedding equality and diversity in the curriculum: Developing and disseminating effective practice, Policy Research Institute and University of 
This is an Accepted Manuscript of an article published by Taylor \& Francis in Innovations in Education and Teaching International (2015), available

online: $h$ ttp://dx.dol.org/10.1080/14703297.2015.1013145 [DOI:

10.1080/14703297.2015.1013145].

Wolverhampton. Available online at:

www2.wlv.ac.uk/equalopps/latee_2_report_FINAL_KT.doc (accessed 16/01/15)

Richardson, J. (2008). Degree attainment, ethnicity and gender: a literature review. York, UK: Equality Challenge Unit, Higher Education Academy.

Ridley, A. M. (2007). Approaches to learning, age, ethnicity and assessment: implications for widening participation. Psychology Teaching Review. 13, 3-13

Strand, S. (2014) Ethnicity, gender, social class and achievement gaps at age 16: intersectionality and 'getting it' for the white working class. Research Papers in Education, 29, 131-171

Stake, R.E. (1995). The art of case study research. Thousand Oaks, CA: Sage.

Stuart, M., Lido, C., Morgan, J., \& May, S. (2008). Student diversity, extra-curricular activities and perceptions of graduate outcomes. Report of a Higher Education Academy Grant 2007-08.

Tinto, V. (1993). Leaving college: Rethinking the causes and cures of student attrition. (2nd Ed.). Chicago: University of Chicago Press.

Trigwell, K., \& Ashwin, P. (2003) Undergraduate students' experience of learning at the University of Oxford. Institute for the Advancement of University Learning.

Willems, J. (2010) The equity raw-score matrix - A multi-dimensional indicator of potential disadvantage in higher education. Higher Education Research \& Development, 29, $603-621$. 
This is an Accepted Manuscript of an article published by Taylor \& Francis in Innovations in Education and Teaching International (2015), available online: $h$ ttp://dx.dol.org/10.1080/14703297.2015.1013145 [DOI:

10.1080/14703297.2015.1013145].

Yorke, M., \& Longden, B. (2008). The first year experience of higher education in the UK. York, UK: Higher Education Academy. 